\title{
An Experimental Study on Solidification of Pure Water or a Dilute Salt Solution in a Horizontal Copper Tube
}

Hwa-Chong Tien

Associate Professor, Department of Mechanical and Marine Engineering, National Taiwan Ocean University, Keelung, Taiwan, R.O.C.

Sih-Li Chen

Professor, Department of Mechanical Engineering, National Taiwan University, Taipei, Taiwan, R.O.C.

Bing-Shiang Yang

Graduate Student, Department of Mechanical Engineering, National Taiwan University, Taipei, Taiwan, R.O.C.

Follow this and additional works at: https://jmstt.ntou.edu.tw/journal

Part of the Mechanical Engineering Commons

\section{Recommended Citation}

Tien, Hwa-Chong; Chen, Sih-Li; and Yang, Bing-Shiang (1997) "An Experimental Study on Solidification of Pure Water or a Dilute Salt Solution in a Horizontal Copper Tube," Journal of Marine Science and Technology. Vol. 5: Iss. 1, Article 9.

DOI: $10.51400 / 2709-6998.2540$

Available at: https://jmstt.ntou.edu.tw/journal/vol5/iss1/9

This Research Article is brought to you for free and open access by Journal of Marine Science and Technology. It has been accepted for inclusion in Journal of Marine Science and Technology by an authorized editor of Journal of Marine Science and Technology. 
An Experimental Study on Solidification of Pure Water or a Dilute Salt Solution in a Horizontal Copper Tube

\section{Acknowledgements}

The authors wish to thank Mr. Kwang-Sheng Chiang for typing the manuscript. This work was performed at the Energy Laboratory, Department of Mechanical Engineering, National Taiwan University. The support of National Science Council of ROC(a short-term project, NSC 83-0115-C-002-0010) is gratefully appreciated. 


\title{
AN EXPERIMENTAL STUDY ON SOLIDIFICATION OF PURE WATER OR A DILUTE SALT SOLUTION IN A HORIZONTAL COPPER TUBE
}

\author{
Hwa-Chong Tien*, Sih-Li Chen** and Bing-Shiang Yang***
}

Keywords: Two phase region, Eutectic point, Supercooling.

\section{ABSTRACT}

Solidification of pure water and $\mathrm{NaCl}-\mathrm{H}_{2} \mathrm{O}$ solutions in a copper tube is investigated experimentally. The morphology and growth of the two phase region is observed photographically. In the experiments of $\mathrm{NaCl}-\mathrm{H}_{2} \mathrm{O}$ solutions, the salt concentrations in the solutions are smaller than the concentration at the eutectic point. The coolant temperature is higher than the eutectic temperature. The supercooling phenomenon and the effects of the coolant temperature, initial temperature of water or $\mathrm{NaCl}-\mathrm{H}_{2} \mathrm{O}$ solution, and the concentrations of the solutions are studied in detail. In addition to the photographs, results presented also include the temperature responses of water and $\mathrm{NaCl}-\mathrm{H}_{2} \mathrm{O}$ solutions at various positions inside the tube as well as the mass fraction of solid. A comparison is made for the mass fraction of solid between the present study and the numerical results in the literature. Possible reasons for explaining the discrepancy are discussed.

\section{INTRODUCTION}

The solidification of pure water and aqueous salt solutions represents two categories of applications. Water is usually used as an energy-carrier fluid in off-peak air-conditioning systems in industry and commercial buildings. The common operation of such air-conditioning systems is to solidify water in the nighttime by utilizing off-peak electricity and then melt the ice in the daytime to provide the cooled air for air conditioning. Since most electric utilities offer special rates for nighttime electricity users, thermal storage air-conditioning systems become

Paper Received January, 1997. Revised April, 1997. Accepted April, 1997. Author for Correspondence: Hwa-Chong Tien.

*Associate Professor, Department of Mechanical and Marine Engineering, National Taiwan Ocean University, Keelung, Taiwan, R.O.C.

*Professor, Department of Mechanical Engineering, National Taiwan University, Taipei, Taiwan, R.O.C.

**Graduate Student, Department of Mechanical Engineering, National Taiwan University, Taipei, Taiwan, R.O.C. more and more popular in the recent years [1].

One of the major problems encountered in the thermal storage air-conditioning systems is supercooling. Usually, ice crystals will not form until the temperature of water falls far below $0^{\circ} \mathrm{C}$ (such as $-7^{\circ} \mathrm{C}$ ). The supercooling phenomenon will consume more electricity and thus decrease the coefficient of performance (COP) of the air-conditioning systems. Therefore, it is essential to study the supercooling phenomenon of solidification of water and find ways to depress such phenomenon.

There are a number of studies which investigate the growth of the ice crystals as well as the supercooling phenomenon of solidification of water such as [2-6]. Due to the close relationship between supercooling and nucleation temperature, there are also some papers focusing on possible variables which affect the nucleation temperature. The variables being studied include the cooling rate of the coolant $[7,8]$, surface roughness of the cooling surface, strength of natural convection [4,9], vibration induced by the external forces, and the purity of water.

Solidification of aqueous salt solution is also of both fundamental and practical importance. It can be applied to many engineering fields, such as antifreeze materials, biological purification, and heat exchanger design, etc. A rigorous work was performed by Fang et. al. [10] where freezing of a dilute $\mathrm{NaCl}-\mathrm{H}_{2} \mathrm{O}$ solution on a cold ice surface was studied experimentally and theoretically. The morphology of the mush zone was observed and a similarity model was developed for the prediction of the freezing rate. Since in [10] the temperature of the ice surface was not constant, Braga and Viskanta [11] investigated solidification of a binary solution on a cold stable isothermal surface. A simplified model was developed to predict the solidification of an aqueous solution (either $\mathrm{NaCl}-\mathrm{H}_{2} \mathrm{O}$ solution or $\mathrm{NH}_{4} \mathrm{Cl}-\mathrm{H}_{2} \mathrm{O}$ solution). Burns et al. [12] numerically studied the solidification of the $\mathrm{NaCl}-\mathrm{H}_{2} \mathrm{O}$ 
solution in a circular cylinder. A simple 1-D heat conduction model accounting for phase change was proposed in [12]. However, the supercooling and the natural convection effects were not included.

In the present work, solidification of pure water or $\mathrm{NaCl}-\mathrm{H}_{2} \mathrm{O}$ solution in a horizontal copper tube is studied. Attention is given to the supercooling phenomenon as well as effects of the coolant temperature, initial temperature of water or $\mathrm{NaCl}-\mathrm{H}_{2} \mathrm{O}$ solution, and the concentration of $\mathrm{NaCl}$. A comparison is made for the results of the solid fraction between [12] and the present study.

\section{EXPERIMENTAL SET-UP AND PROCEDURE}

\section{Experimental Set-Up}

Figure 1 shows the schematic diagram of the experimental apparatus. The test cell consists of a copper tube with $8.28 \mathrm{~cm}$ ID. The copper tube is initially filled with water or $\mathrm{NaCl}-\mathrm{H}_{2} \mathrm{O}$ solution, and cooling process followed by solidification will occur later on. There are two thick acrylic circular disks attached to the forward and backward faces of the copper tube, respectively. An O-ring is used on each side of the tube for seal purpose. It should be mentioned that these thick acrylic disks are transparent for easier observation. The heat loss of the test section is minimized due to the fact that the outer wall of the copper tube is wrapped with insulation materials and also the acrylic disks possess good insulation property. The outer surface of the copper tube is circulated by low-temperature methanol coming from one of the constant-temperature baths. The combination of the tube wall with the cold methanol is used as the thermal boundary condition for cooling and solidification of water as well as

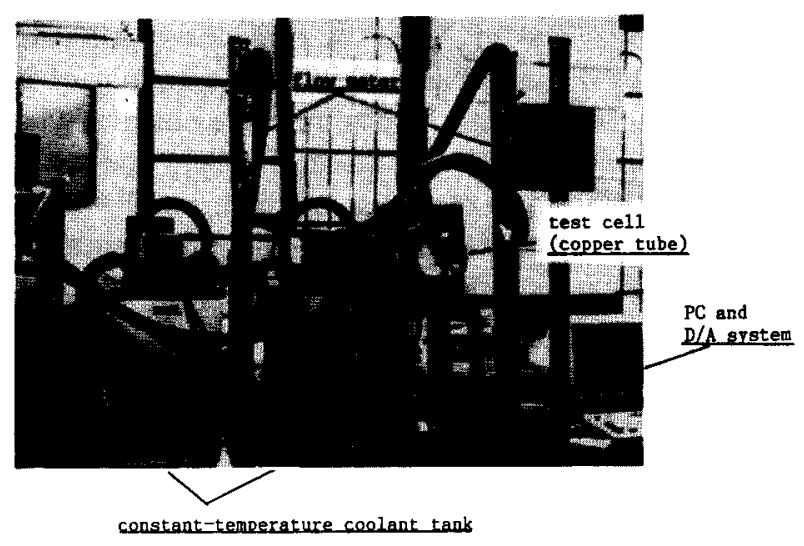

Fig. 1. A photograph of the experimental set-up.
$\mathrm{NaCl}-\mathrm{H}_{2} \mathrm{O}$ solutions. There are four thermocouples (type $\mathrm{T}$ ) installed inside of the copper tube, where one is located at the center, the other three thermocouples are close to the inner wall of the tube. They are separately, at the upper, middle and lower positions. These thermocouples are used for recording the temperature responses of water or $\mathrm{NaCl}-\mathrm{H}_{2} \mathrm{O}$ solution as well as ice at above-mentioned locations. There is a hole drilled at the upper location of the acrylic disk which is attached to the back of the copper tube. This hole is used for the sake of volume expansion or contraction of water or $\mathrm{NaCl}-\mathrm{H}_{2} \mathrm{O}$ solution during the solidification process.

\section{Experimental Procedure}

Distilled water is first boiled to remove the small amount of gases resolved in the water. The boiled water is mixed with certain amount of $\mathrm{NaCl}$ when the $\mathrm{NaCl}-\mathrm{H}_{2} \mathrm{O}$ solution is to be used. The boiled water or $\mathrm{NaCl}-\mathrm{H}_{2} \mathrm{O}$ solution is poured into a container which stands high and the valve is turned on to direct water or $\mathrm{NaCl}-\mathrm{H}_{2} \mathrm{O}$ solution into the copper tube. The outer surface of the copper tube is circulated with coolant (methanol) coming from one of the constant-temperature coolant tank to cool down the boiled water or $\mathrm{NaCl}-\mathrm{H}_{2} \mathrm{O}$ solution until the liquid inside the tube reaches the desired temperature which is served as the initial temperature of the water or $\mathrm{NaCl}-\mathrm{H}_{2} \mathrm{O}$ solution. In the meantime, the second constant-temperature coolant tank is set to a prescribed temperature for cooling and solidifying the water or $\mathrm{NaCl}-\mathrm{H}_{2} \mathrm{O}$ solution in the tube later on.

The data acquisition system is composed of a PCLD-889 signal amplifier, and a PCL-818 A/D card which is connected to a personal computer. The solidification process is observed by taking photographs at representative times. A lamp behind the test section provides the light source which is able to penetrate through the acrylic disks into the camera. The solid ice will absorb part of the light and it will form the dark region of the photographs. On the other hand, the liquid water or $\mathrm{NaCl}-\mathrm{H}_{2} \mathrm{O}$ solution is almost perfectly transparent to the light, and the bright region is formed on the photographs. As a result, the solid/liquid interface can be easily seen from the photographs.

When the water or $\mathrm{NaCl}-\mathrm{H}_{2} \mathrm{O}$ solution inside the tube reaches the prescribed temperature, i.e., the initial temperature, the solidification experiment is right on the way. Methanol from the second constant-temperature cooling tank is introduced to the outer circumferential area of the copper tube, and then the data acquisition system starts recording 
the temperature readings. Photographs are taken during the solidification process at selective times. Each run is terminated at a certain time, which corresponds to a specified Fourier number, Fo, then the solid phase and the liquid phase are weighed separately in order to determine the mass fraction of the solid phase, F. Some experiments need to be repeated several times to get enough data of solid fraction. In the present study, controlling variables include the coolant temperature, the initial temperature of water or $\mathrm{NaCl}-\mathrm{H}_{2} \mathrm{O}$ solution, and the concentrations of NaCl- $\mathrm{H}_{2} \mathrm{O}$ solutions. For simplicity, the inner diameter of the copper tube is $8.28 \mathrm{~cm}$, which is unchanged during the entire course of study.

\section{RESULTS AND DISCUSSION}

In the results presented below, the initial temperature of water or $\mathrm{NaCl}-\mathrm{H}_{2} \mathrm{O}$ solutions is chosen as $0^{\circ} \mathrm{C}$ or $23^{\circ} \mathrm{C}$, and the temperature of the coolant (methanol) is either $-10.5^{\circ} \mathrm{C}$ or $-16.5^{\circ} \mathrm{C}$. As for the concentrations of the $\mathrm{NaCl}-\mathrm{H}_{2} \mathrm{O}$ solutions, three concentrations, $0^{\circ} \mathrm{C}$ (pure water), $3.4 \%$ and $5 \%$ of $\mathrm{NaCl}$ by weight are selected for the sake of comparison with literature. It is noted that the eutectic point for the $\mathrm{NaCl}-\mathrm{H}_{2} \mathrm{O}$ solution is $23.3^{\circ} \mathrm{C}$ at $-21.1^{\circ} \mathrm{C}$. Therefore, the concentrations mentioned above are assumed to be hypoeutectic.

\section{Solidification of Pure Water}

The experimental results for solidification of pure water are first presented due to its direct application on the ice-storage air-conditioning systems and its fundamentality relating to the solidification of $\mathrm{NaCl}-\mathrm{H}_{2} \mathrm{O}$ solutions.

\section{Effect of Coolant Temperature on Solidification}

For the coolant temperature of $-16.5^{\circ} \mathrm{C}$ and the initial temperature of $23^{\circ} \mathrm{C}$, it can be seen in Fig. 2 that the temperature of the lower thermocouple which is adjacent to the inner wall of the copper tube decreases quickly and then starts to solidify. The supercooling phenomenon was not observed for this case. Figure $2(a)$ is the photograph taken at 504 seconds after cooling process began. It can be seen that in Fig. 2(a) a ring of ice formed next to the wall, and ice dendrite was not found for this case. Figure 2(b) depicts the temperature readings of the thermocouples at various locations. It shows that the water temperature decreases almost monotonically. The recalescence phenomenon was not ob- served. However, when the coolant temperature is raised from $-16.5^{\circ} \mathrm{C}$ to $-10.5^{\circ} \mathrm{C}$, as shown in Fig. 3, the results for the coolant temperature of $-10.5^{\circ} \mathrm{C}$ turn out to be quite different from that for the coolant temperature of $-16.5^{\circ} \mathrm{C}$. It is very hard for the water temperatures close to the wall to reach the nucleation temperature. As a result, solidification does not occur until the water temperature decreases to about $-6^{\circ} \mathrm{C}$. Once the ice dendrite appears, the water temperature around it soon increases to $0^{\circ} \mathrm{C}$ due to the evolution of latent heat. Since then, the water temperature around the dendrite maintains at $0^{\circ} \mathrm{C}$ for quite a long time (13 minutes for the upper position) due to the fact that the supercooled water continuously absorbs the latent heat which results from the growth of the ice dendrite. It is also noted that in Fig. 3(a), some ice dendrites appear in the upper

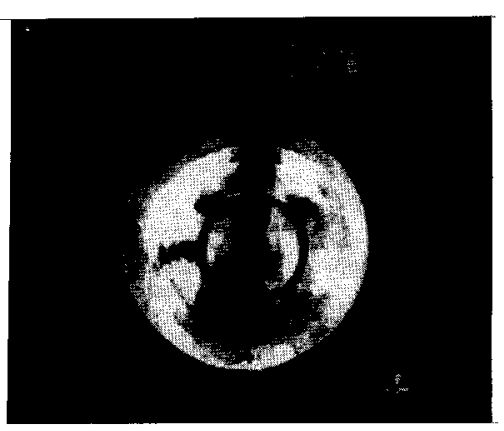

(a)

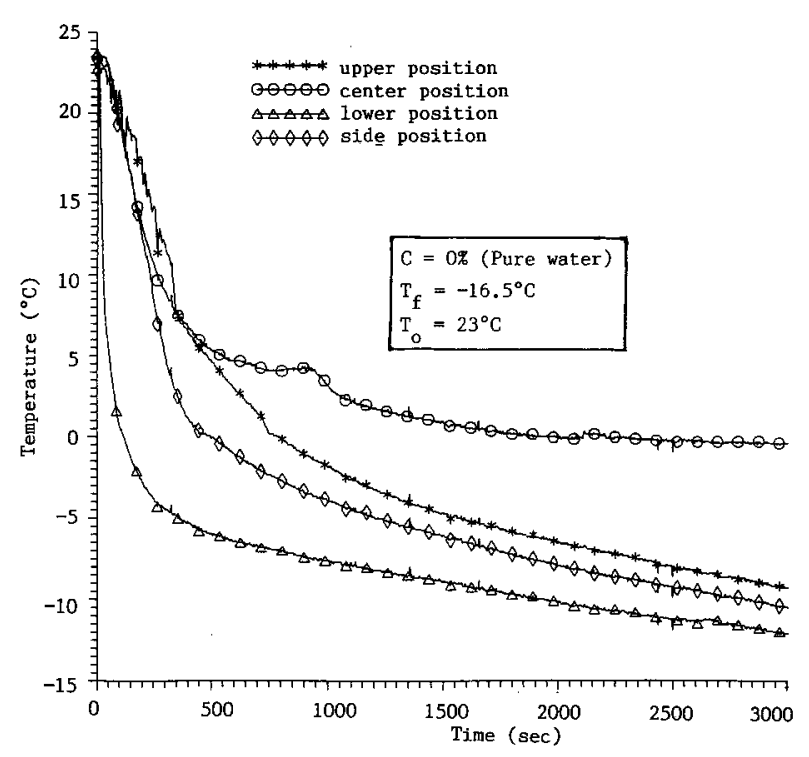

(b)

Fig. 2. (a) A photograph during solidification, (b) temperature responses at various positions for pure water with initial temperature of $23^{\circ} \mathrm{C}$ and coolant temperature of $-16.5^{\circ} \mathrm{C}$. 
region inside of the tube. Based on the above discussion, it is demonstrated that the supercooling phenomenon is greatly enhanced by the increase of the coolant temperature.

\section{Effect of the Initial Temperature of Pure Water}

The effects of initial temperature are examined by choosing two initial temperature $23^{\circ} \mathrm{C}$ and $0^{\circ} \mathrm{C}$, while the coolant temperature is fixed as $-10.5^{\circ} \mathrm{C}$. Figure 4 shows the photographs and the temperature at the upper positions for both cases. It can be seen from Fig. 4(b) that supercooling appears in both cases. Moreover, the supercooling for initial temperature of $0^{\circ} \mathrm{C}$ is slightly larger than that of $23^{\circ} \mathrm{C}$ although the duration of supercooling for both cases are about the same. It is also noted from Fig. 4(a)

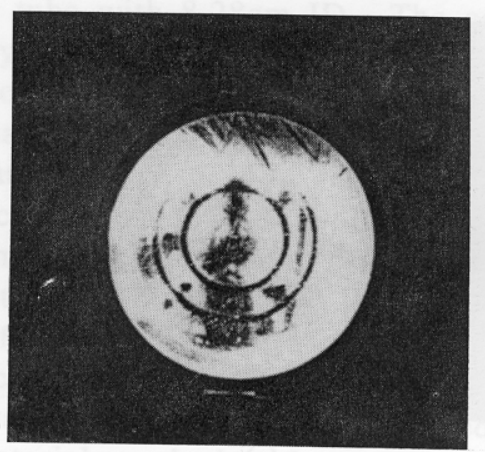

(a)

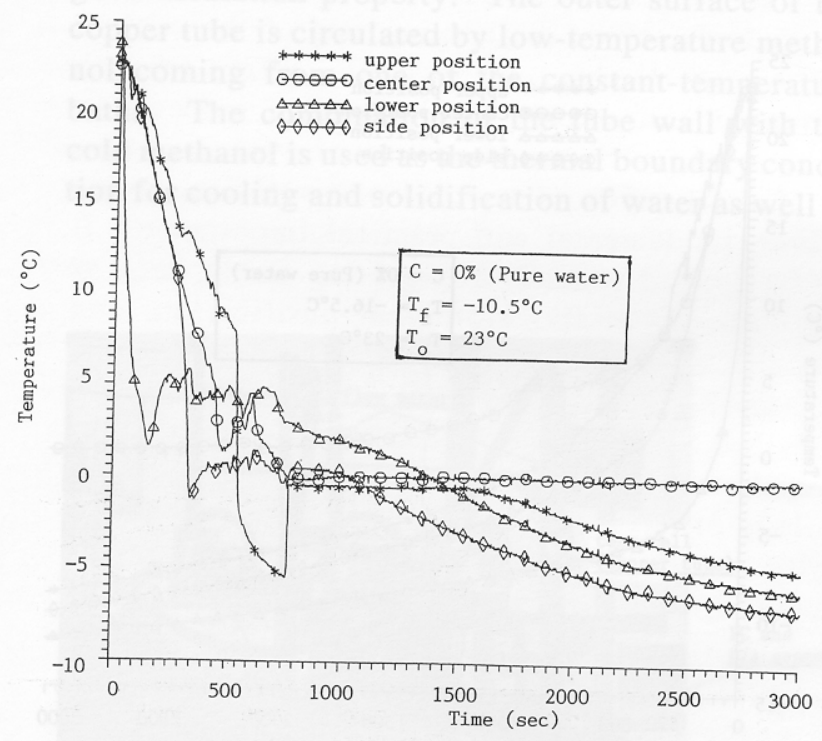

(b)

Fig. 3. (a) A photograph during solidification, (b) temperature responses at various positions for pure water with initial temperature of $23^{\circ} \mathrm{C}$ and coolant temperature of $-10.5^{\circ} \mathrm{C}$. that the upper region occupied by the solid dendrite for the case of initial temperature of $0^{\circ} \mathrm{C}$ is larger than that of $23^{\circ} \mathrm{C}$. According to [5], it can be attributed to the difference in the strength of natural convection for both cases. The lower initial temperature yields smaller temperature difference between the initial temperature and the coolant temperature, and hence weaker natural convection. Solid dendrite under the circumstances of weaker natural convection tends to form and grow more slowly so that the supercooling effect is more pronounced.

\section{Solidification of $\mathrm{NaCl}-\mathrm{H}_{2} \mathrm{O}$ Solution}

\section{Effect of Concentration of $\mathrm{NaCl}$ on Supercooling}

Two cases which correspond to concentrations

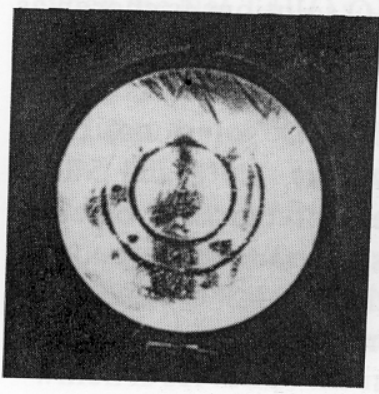

(a)

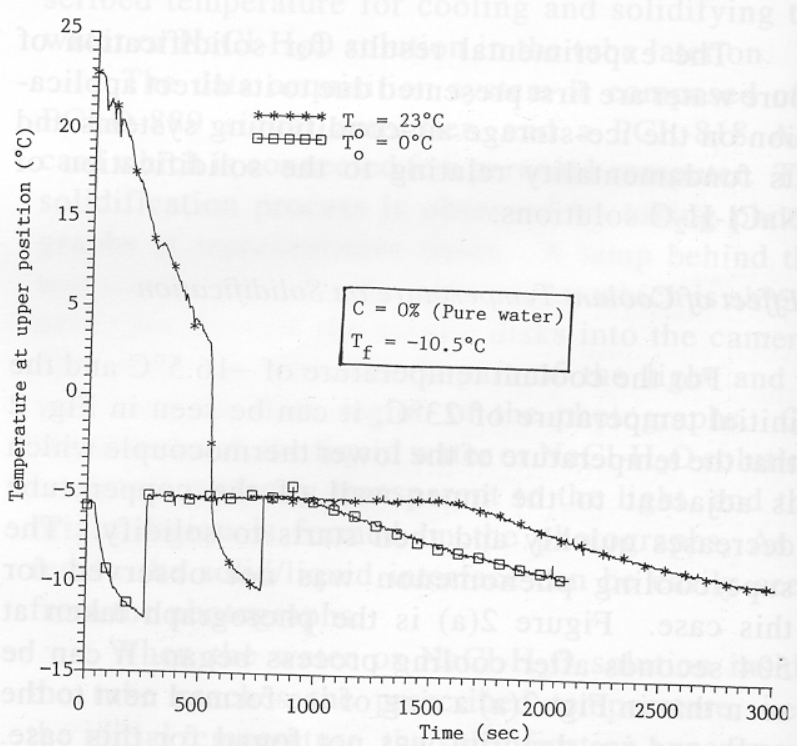

(c)
Fig. 4. Effects of initial temperature on solidification of pure water with coolant temperature of $-10.5^{\circ} \mathrm{C}$, (a) a photograph for $\mathrm{T}_{0}=23^{\circ} \mathrm{C}$, (b) a photograph for $\mathrm{T}_{0}=0^{\circ} \mathrm{C}$, (c) temperature responses at upper position. 
of $3.4 \%$ and $5 \%$ of $\mathrm{NaCl}$ are examined for comparison with the initial temperature of the $\mathrm{NaCl}-\mathrm{H}_{2} \mathrm{O}$ solution and the coolant temperature being fixed as $23^{\circ} \mathrm{C}$ and $-10.5^{\circ} \mathrm{C}$, respectively. The photograph and the temperature responses for the case of $\mathrm{NaCl}$ of $3.4 \%$ are first shown in Fig. 5. It can be seen from Fig. 5 that the lower position of $\mathrm{NaCl}-\mathrm{H}_{2} \mathrm{O}$ solution inside the wall is supercooled, and the time for supercoolong lasts about 11 minutes since the liquidus temperature for $\mathrm{NaCl}-\mathrm{H}_{2} \mathrm{O}$ solution of $\mathrm{NaCl}$ of $3.4 \%$ is $-2.04^{\circ} \mathrm{C}$. Figure 5 (a) shows that the solid dendrite occurs at the lower position. The solid dendrite grows and then occupies more region inside the tube. For brevity, the pictures afterwards are not shown. When the concentration of $\mathrm{NaCl}$ is raised from $3.4 \%$ to $5 \%$, it is shown in Fig. 6 that solid dendrites occur in most region inside the tube. It is

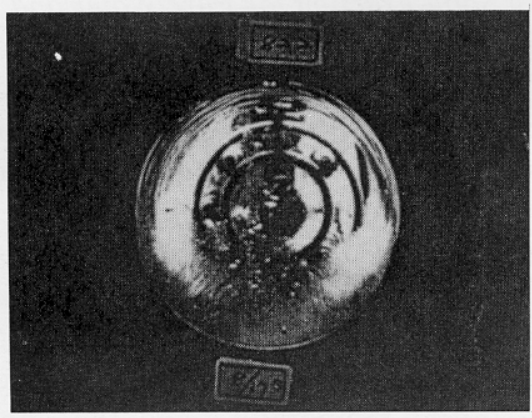

(a)

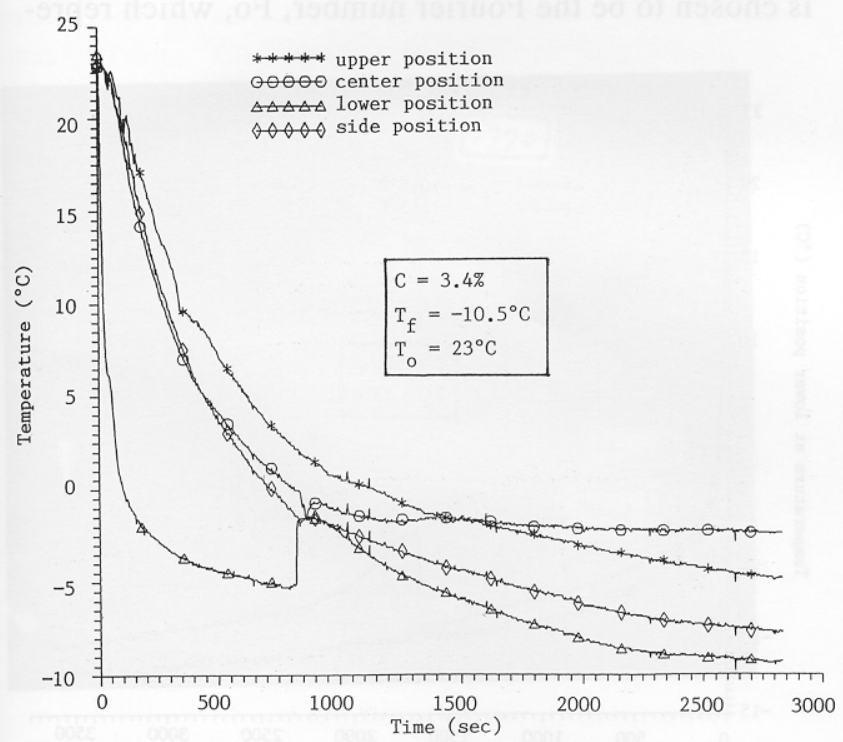

(b)

Fig. 5. (a) A photograph showing solid dendrite, (b) temperature responses at various positions for $\mathrm{NaCl}-\mathrm{H}_{2} \mathrm{O}$ solution with $\mathrm{C}=3.4 \%$, coolant temperature of $-10.5^{\circ} \mathrm{C}$ and initial temperature of $23^{\circ} \mathrm{C}$. noted that relatively large degree of supercooling is found on the lower position. The time for supercooling for this case lasts about 24 minutes, noting that the liquid's temperature is $-3.04 \%$ for $\mathrm{NaCl}$ of $5 \%$. By comparing the temperature at the upper position for pure water with those at lower positions for $\mathrm{NaCl}$ of $3.4 \%$ and $5 \%$, it can be seen clearly from Fig. 7 that an increase in concentration of $\mathrm{NaCl}$ yields an increase in degree of supercooling. This is due to the fact that the liquid's temperature decreases as the concentration of $\mathrm{NaCl}-\mathrm{H}_{2} \mathrm{O}$ solution increases. Therefore, it becomes more and more difficult for the $\mathrm{NaCl}-\mathrm{H}_{2} \mathrm{O}$ solution to solidify, and thus the supercooling phenomenon is enhanced.

\section{Effect of Coolant Temperature on Solidification of $\mathrm{NaCl}$ -} $\mathrm{H}_{2} \mathrm{O}$ Solution

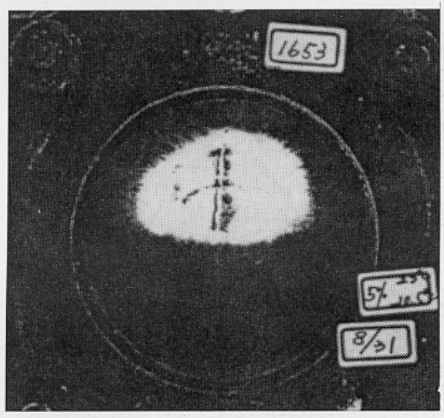

(a)

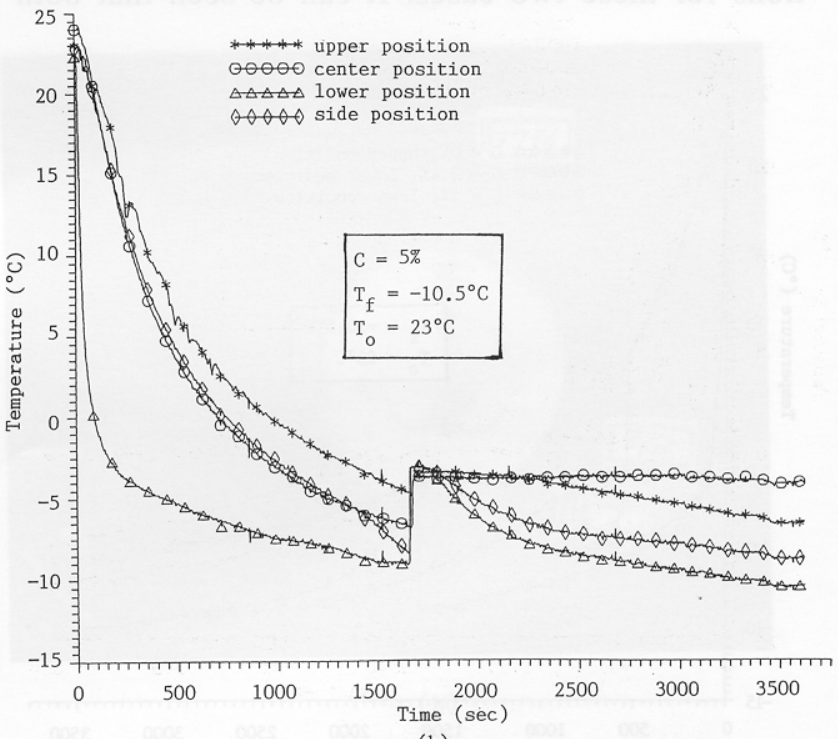

(b)

Fig. 6. (a) A photograph showing solid dendrite, (b) temperature responses at various positions for $\mathrm{NaCl}-\mathrm{H}_{2} \mathrm{O}$ solution with $\mathrm{C}=5 \%$, coolant temperature of $-10.5^{\circ} \mathrm{C}$ and initial temperature of $23^{\circ} \mathrm{C}$. 
As for the cases of pure water, two representative coolant temperatures, $-16.5^{\circ} \mathrm{C}$ and $-10.5^{\circ} \mathrm{C}$ are selected for comparison while the concentration and the initial temperature of the $\mathrm{NaCl}-\mathrm{H}_{2} \mathrm{O}$ solution are $5 \%$ and $23 \%$, respectively. Figure 8 depicts the temperatures at the lower position based on these two coolant temperatures. It is found that supercooling occurs for coolant temperature of $-10.5^{\circ} \mathrm{C}$ where as no supercooling appears for coolant temperature of $-16.5^{\circ} \mathrm{C}$. So the effect of coolant temperature on supercooling for $\mathrm{NaCl}-\mathrm{H}_{2} \mathrm{O}$ solutions is similar to that for pure water. However, it should be mentioned that solid dendrites can be found for the $\mathrm{NaCl}-\mathrm{H}_{2} \mathrm{O}$ solutions at both coolant temperatures. This is due to the fact that the solidification of $\mathrm{NaCl}-\mathrm{H}_{2} \mathrm{O}$ solution is similar to that of common alloys, which usually solidify with dendritic structures. Figures 9 and 10 depict the representative pictures in the course of solidification for coolant temperatures of $-10.5^{\circ} \mathrm{C}$ and $-16.5^{\circ} \mathrm{C}$, separately. It can be found by comparing Fig. 9 with Fig. 10 that more solid dendrites exist for coolant temperature of $-10.5^{\circ} \mathrm{C}$ than for that of $-16.5^{\circ} \mathrm{C}$.

\section{Effect of Initial Temperature of $\mathrm{NaCl}-\mathrm{H}_{2} \mathrm{O}$ Solution}

The effect of initial temperature of $\mathrm{NaCl}-\mathrm{H}_{2} \mathrm{O}$ solution is investigated by choosing two typical temperatures of $0^{\circ} \mathrm{C}$ and $23^{\circ} \mathrm{C}$ while the concentration of $\mathrm{NaCl}-\mathrm{H}_{2} \mathrm{O}$ solutions and the coolant temperature are fixed at $5 \%$ and $-10.5^{\circ} \mathrm{C}$, respectively. Figure 11 depicts the temperature responses at the lower positions for these two cases. It can be seen that both

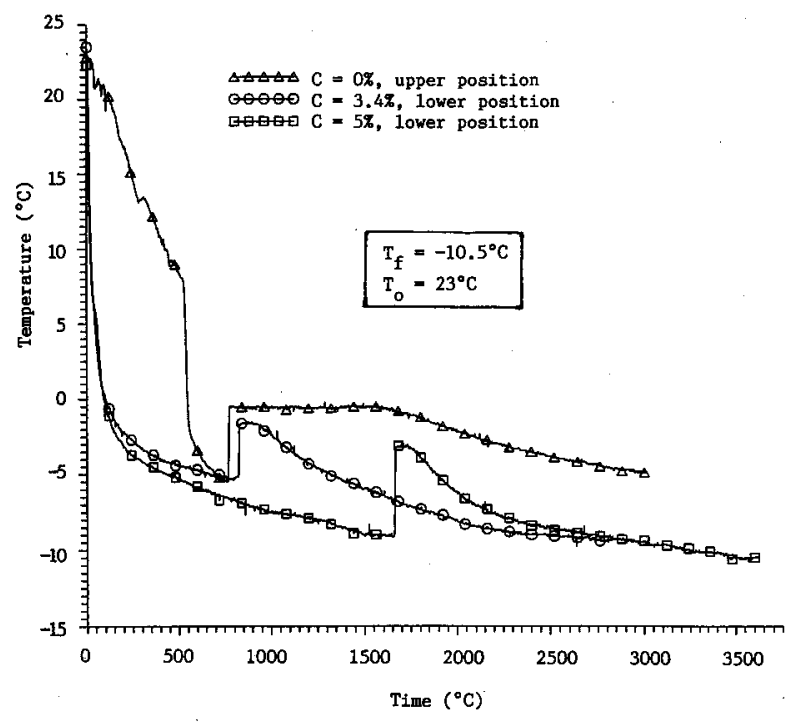

Fig. 7. Effect of concentration of $\mathrm{NaCl}$ in $\mathrm{NaCl}-\mathrm{H}_{2} \mathrm{O}$ solutions with initial temperature of $23^{\circ} \mathrm{C}$, and coolant temperature of $-10.5^{\circ} \mathrm{C}$. cases reveal the existence of supercooling, and the degree of supercooling for initial temperature of $23^{\circ} \mathrm{C}$ is higher than that of $0^{\circ} \mathrm{C}$. Furthermore, the time of supercooling for initial temperature of $23^{\circ} \mathrm{C}$ is much longer than that of $0^{\circ} \mathrm{C}$. It is noted that the effects of initial temperature on the duration time of supercooling for $\mathrm{NaCl}-\mathrm{H}_{2} \mathrm{O}$ solutions are quite different from that for pure water. A possible explanation is attributed to the decrease in liquid's temperature due to an increase in concentration of $\mathrm{NaCl}-\mathrm{H}_{2} \mathrm{O}$ solutions, specifically, $0^{\circ} \mathrm{C}$ for pure water down to $-3.04^{\circ} \mathrm{C}$ for concentration of $\mathrm{NaCl}-\mathrm{H}_{2} \mathrm{O}$ solution of $5 \%$. The coolant temperature of $-10.5^{\circ} \mathrm{C}$ is not low enough for the $\mathrm{NaCl}-\mathrm{H}_{2} \mathrm{O}$ solution, compared with pure water, to quickly arrive at the nucleation temperature (say, $-8^{\circ} \mathrm{C}$ ), and therefore much longer time of supercooling was found for the $\mathrm{NaCl}$ $\mathrm{H}_{2} \mathrm{O}$ solution.

\section{Results of Solid Fraction for Pure Water and $\mathrm{NaCl}-\mathrm{H}_{2} \mathrm{O}$ Solutions}

The results presented above are essentially related to the supercooling phenomenon. In addition to that, the total mass fraction of solid, F, is also quite important in directly characterizing solidification. Figure 12 depicts the results of solid fraction for $\mathrm{NaCl}-\mathrm{H}_{2} \mathrm{O}$ solutions with $\mathrm{NaCl}$ concentrations of $0 \%$ (pure water), $3.4 \%$ and $5 \%$ under the conditions that the initial temperature and the coolant temperature are $23^{\circ} \mathrm{C}$ and $-10.5^{\circ} \mathrm{C}$, respectively. For comparison with literature, the abscissa in Fig. 12 is chosen to be the Fourier number, Fo, which repre-

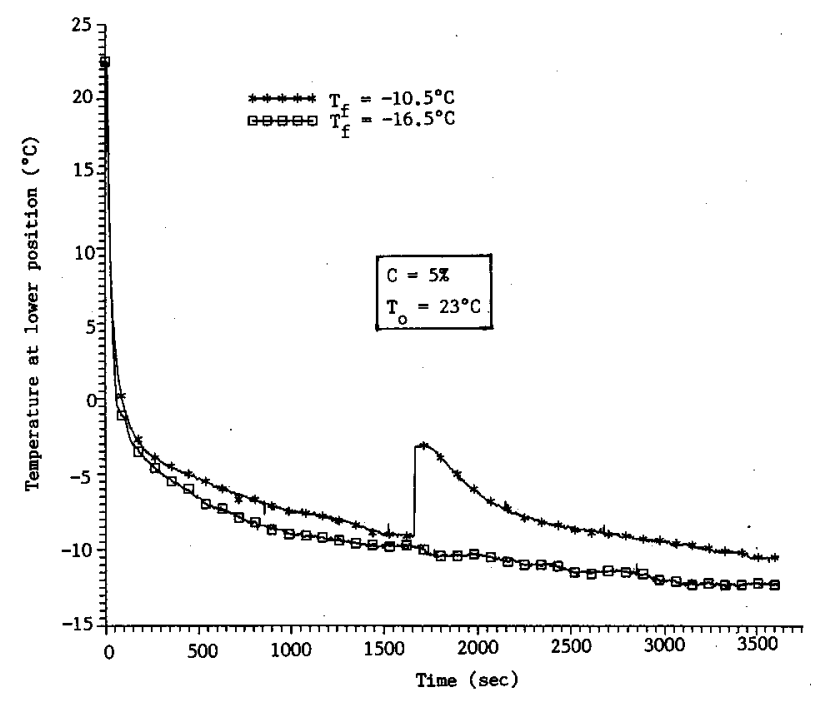

Fig. 8. Temperature responses at the lower position for $5 \% \mathrm{NaCl}-\mathrm{H}_{2} \mathrm{O}$ solution with initial temperature of $23^{\circ} \mathrm{C}$, and coolant temperature of $-10.5^{\circ} \mathrm{C}$ and $-16.5^{\circ} \mathrm{C}$, respectively. 
sents the dimensionless time. The solid lines with various symbols denote the present results while the dashed lines denote the numerical results from [12]. It can be seen from Fig. 12 that the solid fraction increases with time and the slopes of the solid fraction curves decrease as time goes by. Due to supercooling, the time delay for the $\mathrm{NaCl}-\mathrm{H}_{2} \mathrm{O}$ solutions to start solidifying increases as the concentration increases. It should be mentioned that for the $\mathrm{NaCl}-\mathrm{H}_{2} \mathrm{O}$ solutions, the solid dendrite is composed of a single component (ice), and the salt is rejected to the liquid increasing its concentration. Since the coolant temperature $-10.5^{\circ} \mathrm{C}$ is higher than the eutective temperature $-21.1^{\circ} \mathrm{C}$, complete solidification for

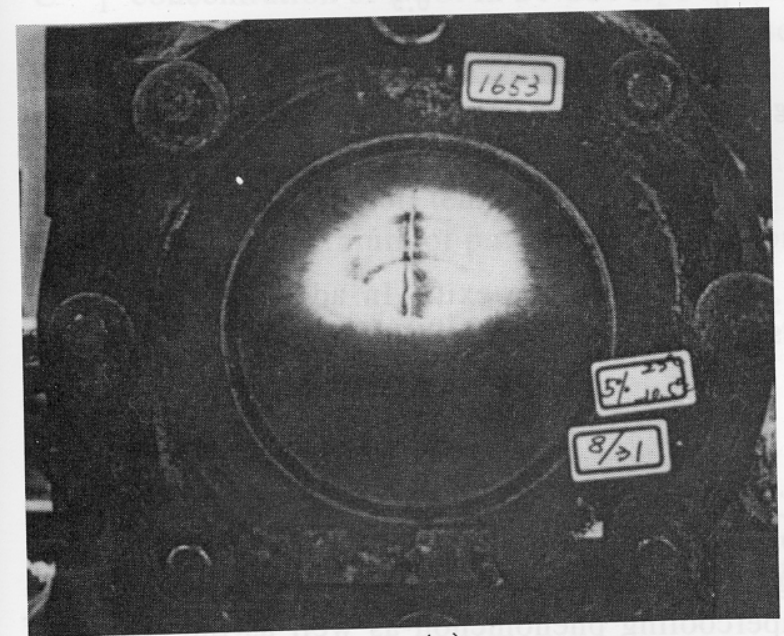

(a)

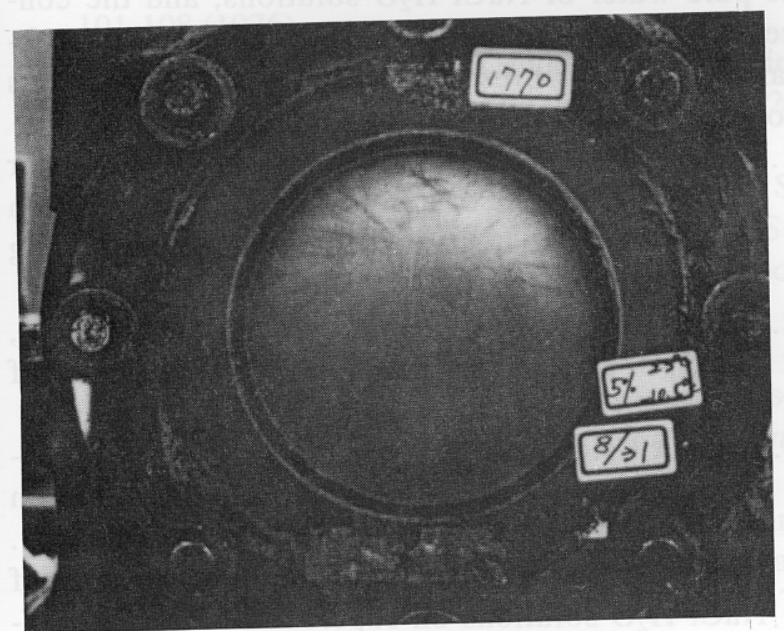

(b)

Fig. 9. Photographs during solidification of the $\mathrm{NaCl}-\mathrm{H}_{2} \mathrm{O}$ solution with $\mathrm{C}=5 \%$, initial temperature of $23^{\circ} \mathrm{C}$ and coolant temperature of $-10.5^{\circ} \mathrm{C}$ (a) photograph right after the occurrence of dendrite ice, (b) photograph at two minutes after (a). the $\mathrm{NaCl}-\mathrm{H}_{2} \mathrm{O}$ solutions can't be achieved. Figure 13 is the same as Fig. 12 except that the initial temperature of $0^{\circ} \mathrm{C}$ is used. Figure 13 looks similar to Fig. 12; however, the influence of the concentration of $\mathrm{NaCl}-\mathrm{H}_{2} \mathrm{O}$ solutions on the time delay for solidification is not so apparent. Both figures display a significant difference between the present results and the results from [12]. Three possible reasons are stated as follows. Firstly, the supercooling effect was completely ignored in [12], and this fact is believed to be the main reason for showing such discrepancy. The second reason is maybe due to the fact that natural convection effects were also neglected in [12]. More accurate mathematical models are

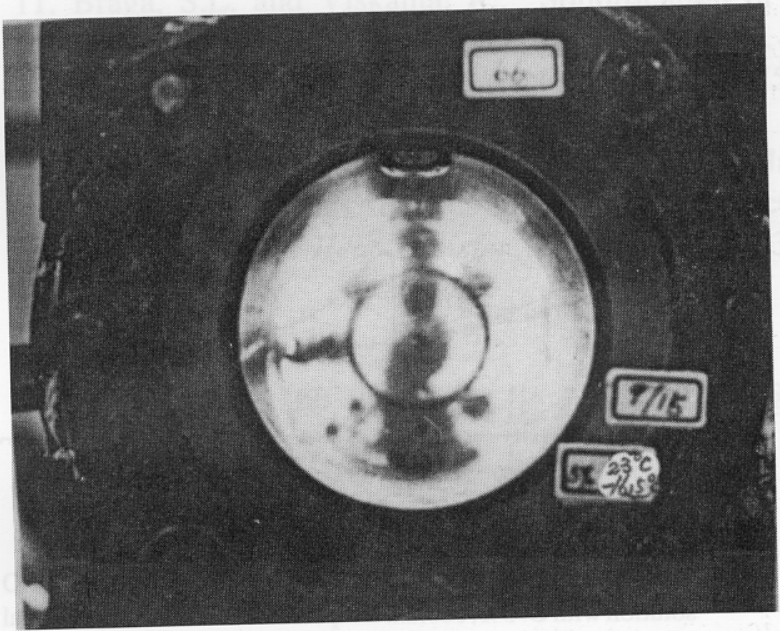

(a)

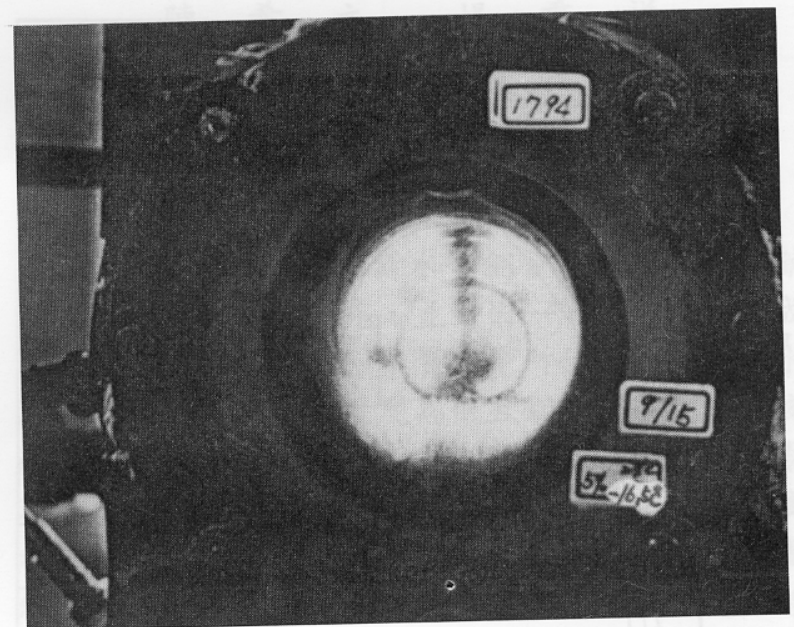

(b)

Fig. 10. Photographs during solidification of the $\mathrm{NaCl}-\mathrm{H}_{2} \mathrm{O}$ solution with $\mathrm{C}=5 \%$, initial temperature of $23^{\circ} \mathrm{C}$ and coolant temperature of $-16.5^{\circ} \mathrm{C}$ (a) photograph right after the occurrence of dendrite ice, (b) photograph at 29 minutes after (a). 
needed in studying the solidification of $\mathrm{NaCl}-\mathrm{H}_{2} \mathrm{O}$ solutions. Thirdly, experimental uncertainty may cause minor effect on the discrepancy. It should be mentioned that the thermocouples used in the present study have been calibrated with errors $\pm 0.7^{\circ} \mathrm{C}$. The difference between the coolant temperatures at the exit and the inlet was found to be about $2^{\circ} \mathrm{C}$. Therefore, the coolant temperature used in this study is based on the average of the coolant temperatures

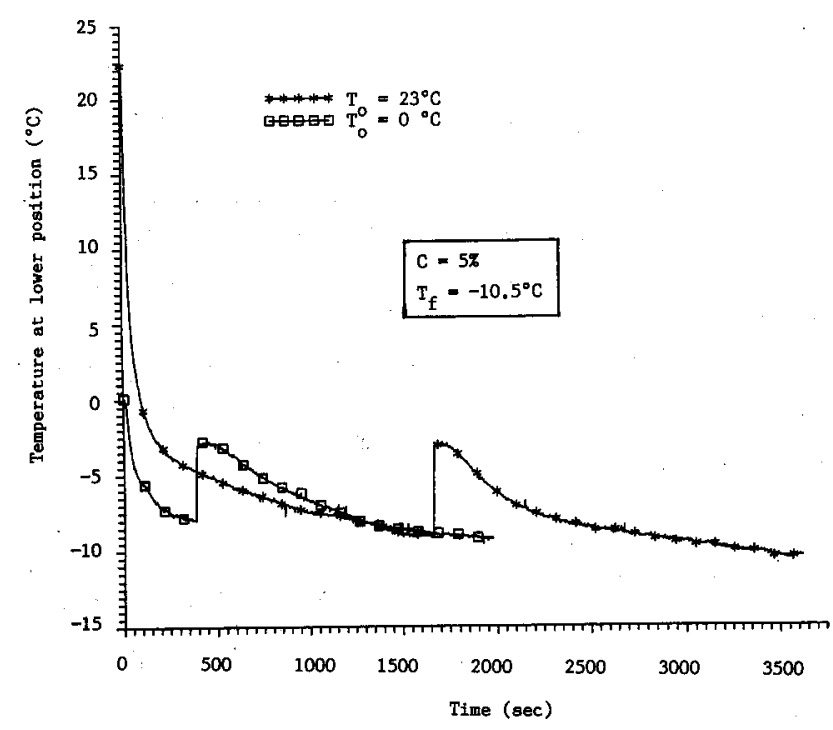

Fig. 11. Temperature responses at the lower position for $\mathrm{NaCl}-\mathrm{H}_{2} \mathrm{O}$ solution with $\mathrm{C}=5 \%$, coolant temperature of $-10.5^{\circ} \mathrm{C}$, and initial temperature of $0^{\circ} \mathrm{C}$ and $23^{\circ} \mathrm{C}$, respectively.

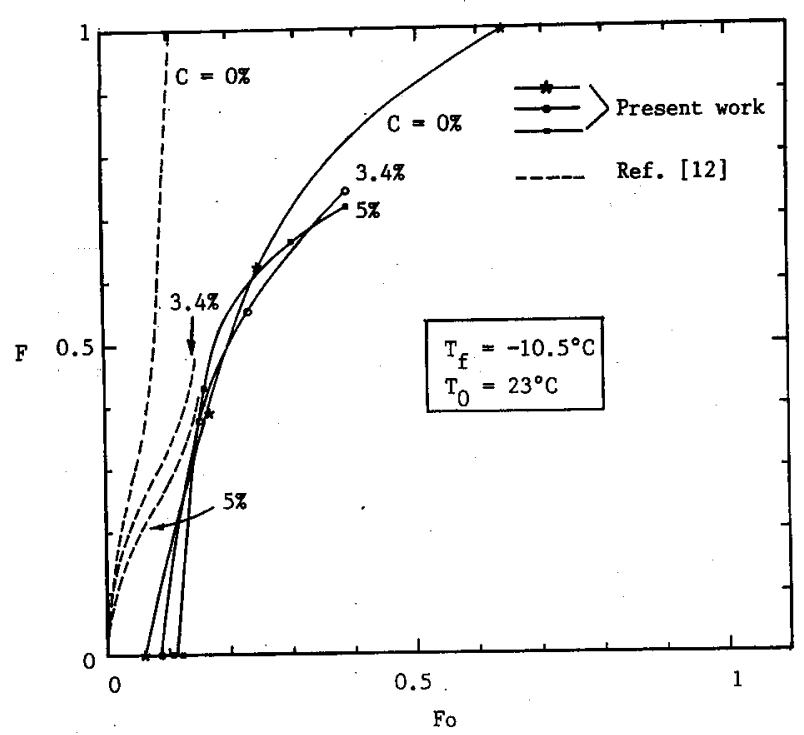

Fig. 12. Mass fraction of solid as a function of Fourier number for three concentrations, coolant temperature of $-10.5^{\circ} \mathrm{C}$, and initial temperature of $23^{\circ} \mathrm{C}$.

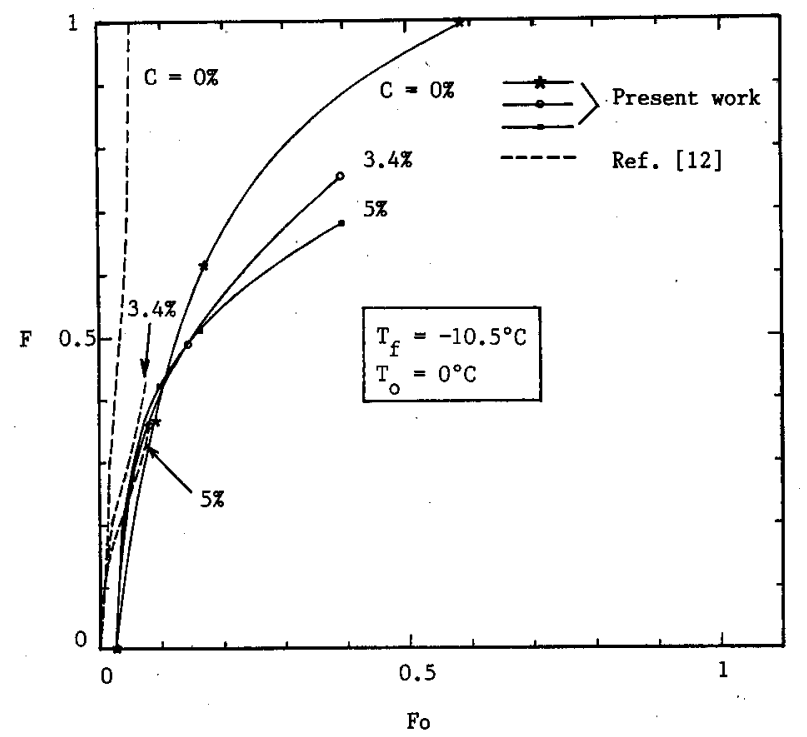

Fig. 13. Mass fraction of solid as function of Fourier number for three concentrations, coolant temperature of $-10.5^{\circ} \mathrm{C}$, and initial temperature of $0^{\circ} \mathrm{C}$.

at the inlet and the exit. In addition, the thermal resistance of the tube wall is neglected.

\section{CONCLUSIONS}

Solidification of pure water and $\mathrm{NaCl}-\mathrm{H}_{2} \mathrm{O}$ solutions in a copper tube was experimentally investigated in this paper. Attention was given on the supercooling phenomenon as well as the effects of the coolant temperature, the initial temperatures of pure water or $\mathrm{NaCl}-\mathrm{H}_{2} \mathrm{O}$ solutions, and the concentrations of $\mathrm{NaCl}-\mathrm{H}_{2} \mathrm{O}$ solutions. The results obtained from the present study can be concluded as follows.

1. Lowering the coolant temperature makes the water close to the wall easier to reach the nucleation temperature and hence to depress the supercooling phenomenon.

2. At medium coolant temperatures, for example, $-10.5^{\circ} \mathrm{C}$, a decrease in the initial temperature of water will increase the degree of supercooling.

3. For $\mathrm{NaCl}-\mathrm{H}_{2} \mathrm{O}$ solutions with hypoeutectic concentrations, the effect of the coolant temperature on supercooling is similar to that of pure water. However, the effect of the initial temperature of $\mathrm{NaCl}-\mathrm{H}_{2} \mathrm{O}$ solutions on supercooling is quite different from those of pure water.

4. An increase in the concentrations will increase the degree and the duration of supercooling .

5. A comparison between the results of solid fraction from the present study and [12] shows significant 
discrepancy. The possible reasons are mainly due to the fact that the effects of supercooling and natural convection were not included in [12].

\section{ACKNOWLEDGMENTS}

The authors wish to thank Mr. Kwang-Sheng Chiang for typing the manuscript. This work was performed at the Energy Laboratory, Department of Mechanical Engineering, National Taiwan University. The support of National Science Council of ROC (a short-term project, NSC 83-0115-C-002-0010) is gratefully appreciated.

\section{NOMENCLATURE}

C concentration of $\mathrm{NaCl}$ in a $\mathrm{NaCl}-\mathrm{H}_{2} \mathrm{O}$ solution F mass fraction of solid = (mass of solid phase)/ (total mass of water or solution)

$\mathrm{F}_{\mathrm{o}} \quad$ Fourier number $=\alpha_{\ell} t / r_{w}^{2}$

$\mathrm{r}_{\mathrm{w}} \quad$ inner radius of the copper tube

$\mathrm{T}_{\mathrm{f}} \quad$ coolant (methanol) temperature

$\mathrm{T}_{0} \quad$ initial temperature of pure water or solution

$t$ time

$\alpha_{\ell} \quad$ thermal diffusivity of water $=1.368 \times 10^{-7} \mathrm{~m}^{2} / \mathrm{s}$

\section{REFERENCES}

1. Lorsch, H.G., Kauffman, K.W. and Denton, J.C., "Thermal Energy Storage for Solar Heating and OffPeak Air Conditioning," Int. J. Heat Mass Transfer, Vol. 18, pp. 1-8 (1975).

2. Gilpin, R.R., "The Influence of Natural Convection on Dentritic Ice Growth," J. Crystal Growth, Vol. 36, pp. 101-108 (1976).

3. Gilpin, R.R., "The Effects of Dendritic Ice Formation in Water Pipes," Int. J. Heat Mass Transfer, Vol. 20, pp. 693-699 (1977).

4. Kashiwagi, T., Itoh, S., Kurosaki, Y. and Hirose, S., "Effects of the Natural Convection in a Partially Supercooled Water Cell on the Release of Supercooling," ASHRAE Trans., Vol. 93, pp. 20-28 (1987).

5. Cheng, K.C., Inaba, H. and Gilpin, R.R., "Effects of Natural Convection on Ice Formation around an Isothermally Cooled Horizontal Cylinder," J. Heat Transfer, Vol. 110, pp. 931-937 (1988).

6. Chellaiah, S. and Viskanta, R., "On the Supercooling during Freezing of Water Saturated Porous Media," Int. Comm. Heat Mass Transfer, Vol. 16, pp. 163-172 (1989).

7. Gilpin, R.R., "The Effect of Cooling Rate on the
Formation of Dendritic Ice in a Pipe with No Main Flow,"J. Heat Transfer, Vol. 99, pp. 419-424 (1977).

8. Saito, A., Utaka, Y. and Okawa, S., "Fundamental Research on the Supercooling Phenomenon on Heat Transfer Surfaces-Investigation of an Effect of Characteristics of Surface and Cooling Rate on a Freezing Temperature of Supercooled Water," Int. J. Heat Mass Transfer, Vol. 33, pp. 1697-1709 (1990).

9. Brewster, R.A. and Gebhart, B., "An Experimental Study of Natural Convection Effects on Downward Freezing of Pure Water," Int. J. Heat Mass Transfer, Vol. 31, pp. 331-348 (1988).

10. Fang, L.J., Cheung, F.B., Linehan, J.H. and Pedersen, D.R., "Selective Freezing of a Dilute Salt Solution on a Cold Ice Surface," J. Heat Transfer, Vol. 106, pp. 385-393 (1984).

11. Braga, S.L. and Viskanta, R., "Solidification of a Binary Solution on a Cold Isothermal Surface," Int. J. Heat Mass Transfer, Vol. 33, No. 4, pp. 745-754 (1990).

12. Burns, A.S., Stickler, L.A. and Stewart, W.E. Jr., "Solidification of an Aqueous Salt Solution in a Circular Cylinder," J. Heat Transfer, Vol. 114, pp. 30-33 (1992).

\section{水平圓管內純水及氯化鈉水溶液固 化實驗分析}

田華忠

國立台灣海洋大學機械與輪機工程挐系

陳 希 立楊 秉 祥

國立台溚大學機械工程學系

摘 要

本文以實驗方法對水平銅管內純水和氯化鈴 水溶液之固化進行研究, 並對固一液兩相區之形成 與發展作観察和照相。本實验中所使用的氯化釣水 溶液㜊度比共晶點之渡度為低且銅管周遥之冷卻液 温度比共晶點之温度為高。本研究之重點在於超冷 現象以及冷卻液温度、純水或水溶液初温與水溶液 之漉度龂固化之影響。賽验結果除了包括照相圆 外，尚有純水及水溶液在管內不同位置之温度記錄 以及固化分率。本文就固化分率結果與既有文驖作 比較，並對造成兩者差異之原因作討論與說明。 